\title{
Fearchur Leighich
}

\section{Author(s): Wm. Morrison}

Source: The Celtic Review, Vol. 2, No. 7 (Jan., 1906), pp. 246-255

Stable URL: http://www.jstor.org/stable/30070155

\section{Accessed: 24-06-2016 06:29 UTC}

Your use of the JSTOR archive indicates your acceptance of the Terms \& Conditions of Use, available at

http://about.jstor.org/terms

JSTOR is a not-for-profit service that helps scholars, researchers, and students discover, use, and build upon a wide range of content in a trusted digital archive. We use information technology and tools to increase productivity and facilitate new forms of scholarship. For more information about JSTOR, please contact support@jstor.org. 


\section{FEARCHUR LEIGHICH}

\section{Captain Wm. Morrison, Army Medical Staff (Retired)}

Tradition is an unreliable basis on which to dogmatise. It has therefore to be taken with the proverbial grain of salt, except so far as circumstantial environments confirm the tradition. Among the many traditions current in Highland ceilidh around the fireside, in my early days, few were given such credence as the story of Fearchur Leighich, physician to the Mackays of Farr.

One of the earliest recollections of my life was the recital of how he came into possession of all the islands and sea-girt rocks between Rudha Storr in Assynt, and Rudha Armidale in Farr. My family was closely related by marriage to a man who claimed to be in the direct male line from this noted physician. He delighted to relate to willing listeners the success of his progenitor in the healing faculty, and the influence he exercised over King Robert the Second in consequence. He was called, it is said, to treat the king after the court physicians had failed to diagnose the ailment from which the king suffered. According to the tradition, the treatment was the acme of simplicity. It was said to be a decoction of boiled milk with wilks and seaweed, a treatment which has to some extent been resuscitated, if we are to believe the advertisements regarding the efficacy of the various patent medicines now extracted from seaweed.

The first charter to confer royal favour on the Leighich was granted by Lord Alexander Stuart-better known in history as the Wolf of Badenoch, fourth son of Robert the Second, and at that period governor of the regions to the north of the Grampians. It conferred on the recipient certain lands in Melness and Hope, and was dated 4th September 1379. This mark of royal favour was confirmed in a second charter, dated 31st December 1386, by King Robert, to which were added all the islands above referred to. The fact that the 'Wolf' made the first grant would presume that it was 
he, and not the king, who came under the physician's treatment, but believers in the tradition in my native parish would probably not accept my theory, the belief being that it was King Robert who was really the patient.

The Durness tradition concerning Fearchur is that he was one of nature's physicians, born in Glengolly, in the Reay Forest, a few miles to the west of Loch Hope, of which Rob Donn says :-

\author{
'Ged a gheibhinn gu m'ailghios, \\ Ceann 't-Sàile Mhic Aoidh, \\ 'S mòr a b' annsa leam fanadh, \\ An Gleanna Gallaidh nan craoibh.'
}

Here he had ample opportunities of acquiring an intimate knowledge of the medicinal properties of the numerous plants and herbs that adorned that lovely glen, finding in nature a cure for all the varied ills of life.

A writer in Scottish Notes and Queries, vol. iv., 2nd series, page 163, gives the following information regarding the subject of our sketch-'Bethune, Farquhar, Wizard Doctor. The most famous wizard doctor of the Highlands, and the first of a family long famous as doctors there. $\mathrm{He}$ was called "Ferchard Leche," and was the leech who, for services to a royal patient, obtained a grant of land from Robert II. in Sutherlandshire in 1386. Strange legends have crystallised round this wizard, who was a native of Islay. $\mathrm{He}$ is said to have become omniscient through taking serpents' broth.'

That the Leighich was a medical migrant from Islay of the name of Beaton was never accepted in the traditions concerning him in Sutherlandshire, and it would be interesting to know where the writer in Notes and Queries found the information on which he based his note.

The first to give the Leighich the name of Beaton was the parish minister of Eddrachillis, the Rev. Alexander Falconer, in his Report of the district in the Old Statistical Account of Scotland, vol. vi., 1793, in which he refers to the grant of the islands as made to 'Ferchard Beaton, a native of Islay.' No 
such tradition as to the Islay origin of the Leighich was ever current in Durness. There were Beatons in Sutherlandshire about the fifteenth century, but they were connected with the Dornoch Cathedral.

I have examined the charters in the Register House, Edinburgh, but the name of Beaton is in neither of them. ${ }^{1}$

The parish minister of Eddrachillis above referred to, in continuation of his remarks, adds the following information regarding the Leighich. - This Ferchard was physician to the Mackays of Farr, and received from them in exchange for his right to these islands (named in the grant of 1386) a piece of ground near Tongue called Melness, where he lived himself, and some of his offspring after him; but the Mackays found means to recover possession of Melness long since, and yet it is said Ferchard's posterity remain still in the country under the name of Mackay.'

It is difficult to reconcile the different versions of the possession of lands in Melness and the Davoch of Hope. One is the statement in the charter found in the Dunrobin Charter Chest by the Commissioner of the Sutherland Estate-James Loch. This charter runs :- 'This is Donald Our M'Corrachy's letter of procuratory as descendit frae Farquhar Leiche to resign all the lands of Strathnaver within written in our Souerane Lordis handis.' On this deed James Loch has written, 'This deed is endorsed in a handwriting of 1660.' The other is the transfer of the same lands from Sir Hugh Mackay of Farr to Donald MacCorrachy under the following circumstances. This Donald was a grandson of Iain Mor, Chief of the MacLeods of Assynt, and at the instigation of the Morrisons of Ashir and the Mackays of Durness he murdered his cousin, James MacLeod-a claimant for the lands of Eddrachillis-in order to put Donald Mackay, a natural son of Sir Hugh Mackay, in possession of the western portion of that district. This Donald Mackay was,

1 It would interest only a few to insert the charters in this sketch, but if any of the readers of the Celtic Review would care to wade through the legal Latin of the period, I shall supply a copy of both charters. 
according to the Rev. Alexander Falconer, the founder of the Scourie branch of the Mackays, but Sir Robert Gordon, makes the founder of that house to have been a son of Iye Mackay by his wife, a daughter of Hugh Macleod of Assynt. Here again we encounter the traditional discrepancies. Donald MacCorrachy could not have renounced in 1511 what he did not possess until about the year 1580 . If it was he who renounced the Melness and West Moin in 1511 he must have been a veritable patriarch at his death in 1619 , one hundred and eight years after he had renounced the Melness lands. After obtaining the West Moin estate, Donald MacMhorchadh Mhic Iain Mhor lived in Fresgill, and was regarded as a scourge to the district. His son William is buried in the old churchyard on the west side of Loch Hope. His grave is marked with a stone bearing a death's head, cross bones, and other symbols of our mortality. If William's father is the Donald MacCorrachy of the 1511 charter, 'descendant frae Farquhar Leiche,' he must have been in the male line, which would have made the Leighich a Macleod instead of a Beaton, and this cannot be disposed of by the crude opinion that the Mackays not only took the lands of their neighbours but obliterated the family names of those whom they despoiled.

The Beatons of Islay did not come into prominence until the year 1511, when one of the name is enrolled for the first time in the records of the Glasgow University. There is an Islay tradition that an Englishman named Cockspur was murdered in Islay in 1370, and that his servant, Duncan Beaton, was rescued by a girl named Grant, whom he afterwards married, and by whom he had two sons, one of whom became a bishop, the other a noted physician. If this tradition has a shred of truth, the dates of the charters above referred to dispose of the legendary connection between Fearchur Leighich and the prominent physicians who came into royal favour during the first quarter of the seventeenth century.

On page 77, Caledonian Medical Journal, 1902, Dr. H. Cameron Gillies enrols Fearchur Leighich among the MacVOL. II. 
Beaths of Islay with as much authority as the Rev. Mr. Falconer had in making him a Beaton.

My object in writing this paper, however, is not so much to prove whether Fearchur was a Beaton, a MacBeath, or a Mackay, as to print the song of the islands which, I believe, has not before appeared in print. I have not heard it recited since I was ten years of age, when its singularity, if not its rhythm, fixed it in my memory. I have failed to trace the author, who, I imagine, must have been a sailor who traded between Lochinver and the Caithness ports. The Old Statistical Account gives the islands as from Rudha Storr to Stroma, from which it may be inferred that the song was current in those days, as the charter goes no further than from Rudha Storr to Rudha Armidal in the parish of Farr.

\section{ORAN NAN EILEAN}

1. Chi mi Suana mhór's an tide, Beagan an taobh shios do Arcudh, Chi mi Dungasbaidh is Stròma, Far an trie na sheòl mi seachad.

2. Chi mi Ceanna Dhunnat gu mór ann, Ceanna Thoi'thidh 's an Ceanna beag ann, Mach bho na sean chi mi Sannsaid 'S fad a thall bhuam chi mi Arcudh.

3. Chi mi Rudha Shrathaidh gu h-iosal, Far an tric 'n a lion mi mo sheòl air, Eilean nan Naoimh bhithinn taghal, 'S mi fradhraic Eilean nan Ròn ann.

4. Chi mi eileanan an t-Seana Ghoill, Ma thimchioll gu tric 'n a stad mi, Eilean a' Chaoil 's e glé bhòidheach, Sgeir an Òir's an t-Eilean Cragach.

5. Chi mi sean an Ceanna geal ann, 'S na tha do dh' eileanan fo air, Eilean Hothan 's an Dubhsgeir, 'S ann an Ruspuinn gheibhinn còmhnuidh.

6. Chi mi Goillisgeir is Clobhraig, 'S n' thaobh thall tha sgeir a' Bhuic ann, Eilean a' Chobhairidh shuas ann, Far an tric an robh sguaib agus guit ann. 
7. Chi mi 'n Fharaid ghorm mur b' àbhaist, Is na pairceachan aig mo Lord ann, Chi mi 'n Gairbh Eilean mór air a tharsuinnt, 'S chi mi Glaisleacan nan eòin ann.

8. Chi mi 'n Clò 's Creag na Seobhaig, 'S bu teare a bha 'n leithid 's an Roinn-Eòrpa, 'S ainmig chaidh mi riamh seachad Nach do shràc mi mo sheòl oirr.

9. 'Sealltuinn suas air a gualainn, Chi mi 'n Dùnan làn do chòsaibh, 'S mach bho 'n sin chi mi 'n Duisleac, Sùla-sgeiridh agus Ròna.

10. Chi mi 'm Balg 's Rudh' a' Bhuachail, 'S mi 'g ambaire suas air m' aghart, Chi mi 'n Dubhsgeir 's na Clobhsaich, 'S bith na Clobhsaichean na m' fradhare.

11. Chi mi Eilean a' Chonnaidh, Suas bho na sean chi mi Aisir, A' Ghlaisleac an taobh thall do 'n chaolais, 'S i sint ri Lochan Ceann Sàilidh.

12. Eilean nan Ròn 's e glé ainmeil, Is na tha thimchioll air do sgeirean, Chi mi sean Eilean a' Chruadal, Suas gu Eilean na Saille.

13. Chi mi eileanan Loch Lusard, Far an tric an robh mi le bàta, 'S lionmhor acarsaid gun iomradh, Tha eadar 'n Inbhir' 's an Spàrdan.

14. Mach bho na sean Rudha 'n Tiompain, 'S Eilean Shannda air a tharsuinnt, Eilean a' Bhuic is an Cruachan, 'S ged fada bhuam, chi mi Ghlaisleac.

15. Chi mi eileanan Bhad-choill ann, Ma Eilean a' Chùirn gun do stad mi; Tha Eilean a' Bhreithimh gun dórainn, Calbha Mhór 's Calbha Bheag ann.

16. Eilean Alldanaidh glé bhòidbeach, Rudha Stòrr an ceann na h-uidh, Buinidh gach aon dhiubh do mo Lord-sa, Ach 's ann a bha chòir bho Fearchur Leighich. 


\section{THE CELTIC REVIEW}

17. 'S iomadh oidhche fliuch is fuar, Ri tonnaibh cuain is muir tarsaint, 'S cha do reub mi de cuid seòlaibh Feadh an oirlich do thombaca.

18. Ged tha mis an diugh gun bhàta, Dearbh cha b' abhaist domh bhi do h-eas[bh]uidh, Ach Mhic-Aoidh mu rinn thu m' fhàgail, Gu m' fad 's an àit thu cumail ceartais.

\section{TRANSLATION}

1. I see Suana in the tide, ${ }^{1}$ Somewhat below Orkney, I see Duncansby and Stroma, Often have I sailed past them.

2. Dunnet Head is looming largely, Hoy and Holborn in the distance, Sandside I see out from them, And far over from me I see the Orkneys.

3. Lying low I see the point of Strathy, Where oft the breeze has filled my sails, I would sight the Isle of Saints, ${ }^{2}$ While viewing the Isle of Seals.

4. Near me are the Isles of Strangers ${ }^{3}$ Where in safety oft I've anchored, Isle of the Strait in rich adornment Near Gold Skerry and Rocky Island.

1 There is no apparent reason why the author of the song should have begun at Suana, unless to emphasise the difficulty of navigating the Pentland Firth. The islands of Suana and Stroma formed part of the Orcadian parish of Wall and Flotta. The velocity of the tide at Hoy Head in spring tides is seren miles an hour, and three in neap tides. This was sufficient reason for any careful mariner to keep at some distance from either shore.

2 The first of Fearchur's possessions are at the mouth of the Kyle of Tongue. Eilean nan Ròn is of considerable size and supports twelve families in comparative comfort. The soil is fertile, the whole island being under cultivation. Passing under the island is an arch one hundred and fifty feet span and seventy feet broad. The rocks are conglomerate, resting on red sandstone, more prominent in the north end of the island, and stratified in the direction of W.S.W. at an angle of $10^{\circ}$.

Eilean nan Naoimh bears trace of a sacred edifice having been there at some remote period. It was probably used as a burial ground when wolves prowled the Sutherlandshire forests. It has several caverns through which the sea in rough weather spouts to a height of more than thirty feet.

3 Eilean nan Gall, originally Islands of Strangers, better known now as the Rabbit Islands, are three in number. The soil, being sandy, provides excellent cover for the rabbits. 
5. Viewing now the Whiten Head With the isles that lie beyond it, Isle of Hoan and the Black Skerry, But in Rispond I conld tarry.

6. I see Goileskeir and Clourig," And on the far side I see the Buck-rock, Island Chvarie lying westward, Here sheaf and fan denoted plenty.

7. Farout Head, green as was its wont, ${ }^{3}$ Is apportioned to my Lord, Great Garveilan I see lying across, And I see Glaisleac, haunt of birds.

8. The Nail-stack and the Hawk-rock ${ }^{4}$ Scarce their like is found in Europe, Seldom I passed beyond them But my canvas was torn.

9. Looking o'er the Black-flag shoulder I see the Dunan with caves in plenty, Out beyond I see the Duisleac, Sulaskerry and Rona.

10. I see the Blister and Shepherd's Headland, And, glancing westward before me, I see the Black Skerry and the Cleft Isle, With the Cleft Rocks full in view.

11. I see the Isle of Brushwood, And up from that I see Ashir, Grey-flag on the far side of the strait, Stretched beside Loch Kensaly.

1 Eilean Hoan, a mile in length and half a mile in breadth, once supported five crofters (enjoying a portion of the mainland hill pasture), until expatriated in 1838 by the tacksman of Rispond. Of these, two families emigrated to America, the others were compulsorily settled on the congested and arid crofts of Lerin and Smoo.

2 Eilean Chlobhraig, near the inner end of Loch Eriboll, once supported three crofting families, but is now attached to the Eriboll farm. It has a valuable limestone quarry which, owing to cost of transport, has for some time been abandoned.

3 Farout Head is a formation of grey slate, while the region lying between the Kyle of Durness and Loch Eriboll is an immense bed of limestone of unknown depth.

4 The Hawk-rock is the extreme point of the Farout Head, and like Stack Clo (on the opposite side of the Bay of Balnakeil), is about six hundred feet high, and is the summer residence of thousands of the puffin tribe who hatch their young here. These feathered sojourners have immunity from raiders since the passing of the 'Wild Birds' Protection Act,' and are now as great a pest in those waters as the steam trawlers, but, unlike the latter, they are outside the jurisdiction of the Sheriff Court. 


\section{THE CELTIC REVIEW}

12. The renowned Isle of Seals, And all the reefs there are about it, Eilean Chruadal I see there, And up to the Isle of Fatness.

13. I see the islands of Loch Laxford, Where oft I have taken a boat, Anchorages lie in numbers, Between the Inver and the Roost.

14. Outside of these stands the Knoll Point, With Handa standing there obliquely, ${ }^{1}$ Buck Isle and the Cruachan, And though far away I see the Grey-flag.

15. I see the islands of Badcall, And I have tarried at the Isle of the Cairn, The Judge's Isle is now less baneful, ${ }^{2}$ Great Calva and Little Calva are there.

16. Isle of Oldaney most beautiful, ${ }^{3}$ Near Point of Storr, where ends my journey ; All those islands own his Lordship, But their right came from Fearchur Leighich.

17. Many a cold wet night I royaged Ocean waves and cross seas, Nor e'er destroyed of her cordage, The length of an inch of tohacco.

1 A cluster of islands, about twenty in number, lie between Shegra and Assynt. The most notable of these is Handa, rising perpendicular to a height of six hundred feet, and in its crevices myriads of sea-fowl sojourn for the season.

The geological formation of this island is most interesting, lying horizontally as if superimposed by the ingenuity of man. Handa once was tenanted by twelve families, but was added to the factor's farm when the eviction fever spread over Sutherlandshire. It was once the residence of Iain MacDhoil mhic Huistean of the Assynt MacLeods, a branch of Siol Torquil of Lewis. This warrior was the murderer of John Morison, the Lewis Breitheamh, in revenge for the murder of Torquil Dubh.

2 After the murder of John Morison by MacLeod of Handa, a party of Lewis men took the judge's body from Inverkirkag for burial in Stornoway. They were driven by storm on to one of the islands in the Bay of Badcall since called Eilean $a^{\prime}$ Bhreitheimh. Here they disembowelled the body, and proceeded on their journey when the storm abated. This incident took place in the year 1601. The murderer went over to Lewis and married his victim's widow, from which the inference is that the possession of Bathsheba was the real cause of the murder rather than the avenging of Torquil Dubh's death.

3 Of the islands in the Bay of Badcall none appear to be of much value except Eilean Auldney, which now forms part of the pasturage of the sheep farm of Ardvaar. 
18. Though I'm now without a boat, Sure 'twas not my wont to be without one, But Mackay, though thou hast forsaken me, Long may'st thou remain to give us justice.

\section{THE FIONN SAGA}

\section{(Continued from p. 153.)}

George Henderson, M.A., B.Litt., Рн.D.

THE CAMPBELL OF ISLAY RECENSION-(continued)

\section{Fionn's Return}

AT that time (as Mac Cisaig said in Uist) people were few in Alba. There were great empty glens with a man in them here and there, not as it is to-day when men abound in Scotland. There were many deer in these days, and men hunted them.

Fionn knew by his knowledge that his father's men were there and in great straits. So he set off to seek them. They were on the land of the king of Lochlann, as it appears; and the king would not keep them in meat. They had oaken skewers in their bellies to keep them out from their backs, they were so gaunt, and thin, and starved. They had to hunt for the king, but he did not give them enough to eat. They lived in a cave, or, according to others, in a sheiling (bothan-àiridh).

Fionn, with his sword under his arm and Bran at his heels, walked to the dwelling and looked in. ${ }^{1}$

'I will go in and stay,' said he, ' unless I am turned out.'

There was no living thing there but the fire. Swords were there leaning against the wall, rusty old swords and spears, and there were beds and benches.

As no one was there to hinder him, Fionn leaned his sword, Mac-A-Luinn, against the wall, and stretched himself

1 According to others Ireland was the place; or Lochlann, to which the lad walked after he had walked all over Ireland. 